\title{
HbQ-India associated with microcytosis: An uncommon hemoglobin variant associated with a common hematologic condition
}

\author{
Mikrositoz ile ilişkili HbQ-India: Yaygin bir hematolojik durumla \\ ilişkilendirilen yaygin olmayan bir hemoglobin varyantı
}

\author{
Amit Kumar Yadav, Usha Rusia \\ Department of Pathology, University College of Medical Sciences, New Delhi, India
}

\begin{abstract}
HbQ-India is a rare alpha chain variant that usually presents in the heterozygous state. Normally, $\mathrm{HbQ}$-India is clinically silent. It becomes symptomatic when present in association with other conditions. We report a case of HbQ-India with concomitant presence of iron deficiency anemia.

A 16-year-old female presented with weakness and pallor intermittently for six years. Complete blood count showed severe microcytic hypochromic anemia. Hemoglobin electrophoresis showed a prominent band in the S,D,G region. Tests for sickling were negative. High performance liquid chromatography (HPLC) showed a peak in the unknown window (4.70-4.90 min) suggestive of HbQ-India. Serum iron profile was suggestive of iron deficiency anemia. Based on the above findings, a diagnosis of coexistent $\mathrm{HbQ}$-India-iron deficiency anemia was made. A family study revealed the father as having moderate anemia with similar findings while the mother was normal. Abnormal hemoglobin in the patient was confirmed by molecular diagnosis.

$\mathrm{HbQ}$ variants are the alpha globin chain variants due to structural mutations ( $\alpha 64 \mathrm{Asp} \rightarrow \mathrm{His})$ inherited in autosomal dominant fashion. Three molecular variant types have been documented, namely $\mathrm{HbQ}$-India, HbQ-Thailand and HbQ-Iran. Normally, $\mathrm{HbQ}$ is clinically silent. Therefore, careful screening of the samples using routine techniques like $\mathrm{Hb}$ electrophoresis and HPLC are needed for identification of such abnormal hemoglobin variants like HbQ-India. (Turk J Hematol 2010; 27: 200-3)

Key words: $\mathrm{HbQ}$-India, $\mathrm{HbQ}$, hemoglobin variants
\end{abstract}

Received: March 12, 2008

Accepted: April 8, 2009

Özet

Hb Q-India genelde heterozigoz durumda bulunan nadir bir alfa zincir varyantıdır. Normalde HbQIndia klinik olarak sessizdir. Diğer koşulların varlığı ile birlikte semptomatik hale gelir. Biz burada, demir eksikliği anemisi ile eşzamanlı bir HbQ-India vakasını bildiriyoruz.

Altı yaşından beri halsizlik ve gidip gelen solgunluğa sahip 16 yaşında bir kadın sunulmuştur. Tam kan sayımı şiddetli derecede mikrositik hipokromik anemi göstermiştir. Hemoglobin elektroforezi S, D, G 
bölgesinde belirgin bant göstermiştir. Oraklaşma testleri negatiftir. High performance liquid chromatography (HPLC) bilinmeyen pencerede (4,70-4,90 dakika) yaptı̆̆ı pik ile HbQ-India öne sürmüştür. Serum demir profili ise demir eksikliği anemisine işaret etmiştir. Yukarıdaki bulgular temel alınarak eşlik eden HbQ-India-Demir eksikliği anemisi tanısı konmuştur. Aile çalışması annenin normal olmasına karşın babanın benzer bulgularla orta şiddette anemisi olduğunu ortaya çıkarmıştır. Hastada anormal hemoglobin moleküler teşhis ile onaylanmıştır.

$\mathrm{Hb} Q$ varyantları otozomal dominant şekilde kalıtılan yapısal mutasyonlardan ötürü ( $\alpha 64 \mathrm{Asp} \rightarrow \mathrm{His})$ alfa globin zincir varyantlarıdır. HbQ-India, HbQ-Thailand ve HbQ-Iran olmak üzere üç moleküler varyant türü belgelenmiştir. Normalde $\mathrm{HbQ}$ klinik olarak sessizdir. Bu nedenle $\mathrm{Hb}$ elektroforezi \& HPLC gibi rutin tekniklerden yararlanılarak numunelerin dikkatle izlenmesi HbQ-India gibi anormal hemoglobin varyantlarının tanımlanabilmesi için gereklidir. (Turk J Hematol 2010; 27: 200-3)

Anahtar kelimeler: Hb Q India, Hb Q, Hemoglobin varyantları

\section{Introduction}

HbQ-India is a rare alpha globin chain variant and usually presents in the heterozygous state. Normally, HbQ-India is clinically silent. It becomes symptomatic when present in association with other conditions like beta-thalassemia, alphathalassemia, $\mathrm{HbE}$ and $\mathrm{HbH}$. We determined one such case in a Punjabi family. The hematological findings of the case along with the family study are presented.

\section{Case Report}

An 18-year-old female presented with complaints of weakness and pallor intermittently for six years. Physical examination showed severe pallor. No other significant finding was noted. The findings of the complete blood count (CBC) with erythrocyte sedimentation rate (ESR) are summarized in Table 1.

Peripheral smear showed severe microcytic hypochromic anemia. Hb electrophoresis (TEB Buffer $\mathrm{pH}$ 8.6) showed a prominent band in the $\mathrm{S}$, $\mathrm{D}, \mathrm{G}$ region in the patient and father while that of the mother showed a normal pattern. Test for sickling and solubility test were negative in both the patient and her father. Serum iron profile of the patient was: serum iron: $41 \mathrm{mg} / \mathrm{dl}$, total iron-binding capacity (TIBC): $556 \mathrm{mg} / \mathrm{dl}$, and transferrin saturation: $7.4 \%$. High performance liquid chromatography (HPLC) showed a prominent peak in the unknown window (4.70-4.90 min) in both the patient (Figure 1) and her father. The exact percentages of various fractions are summarized in Table 1. HbQ-India was found to be $19.5 \%$ in the patient and $22.5 \%$ in the father. Serum iron profile of father was: serum iron:

Table 1. Results of complete blood count and percentages of various hemoglobin fractions obtained by HPLC

\begin{tabular}{|c|c|c|c|c|c|c|c|c|c|c|c|}
\hline & $\begin{array}{l}\mathrm{Hb} \\
\mathrm{g} / \mathrm{dl}\end{array}$ & $\begin{array}{c}\text { RBC } \\
10^{12} / \mathrm{L}\end{array}$ & $\begin{array}{c}\text { Hct } \\
\%\end{array}$ & $\begin{array}{c}\text { MCV } \\
\text { fl }\end{array}$ & $\begin{array}{c}\mathrm{MCH} \\
\text { pg }\end{array}$ & $\begin{array}{c}\text { MCHC } \\
\text { g/dl }\end{array}$ & $\begin{array}{c}\text { Retic. } \\
\%\end{array}$ & $\mathrm{HbA}_{2}$ & HbA & $\begin{array}{l}\text { HbQ- } \\
\text { India }\end{array}$ & $\mathrm{HbF}$ \\
\hline Patient & 5.8 & 3.52 & 18.8 & 53.3 & 16.4 & 30.7 & 1 & 0.9 & 72.8 & 19.5 & $<1$ \\
\hline Father & 9.5 & 5.07 & 32.9 & 65 & 18.7 & 26.8 & 3 & 0.9 & 64.2 & 22.5 & $<1$ \\
\hline Mother & 11.3 & 4.03 & 33.8 & 83.9 & 28 & 33.3 & 1 & -- & -- & -- & -- \\
\hline $\begin{array}{l}\text { Patient } \\
\text { (Post iron therapy at } \\
3 \text { months) }\end{array}$ & 9.7 & 4.52 & 29.8 & 66 & 22.1 & 34 & 3.5 & -- & -- & -- & -- \\
\hline $\begin{array}{l}\text { Patient } \\
\text { (Post iron therapy at } \\
6 \text { months) }\end{array}$ & 12.9 & 4.65 & 38.9 & 84.1 & 27.8 & 33.1 & 1.5 & -- & -- & -- & -- \\
\hline $\begin{array}{l}\text { Father } \\
\text { (Post iron therapy at } \\
3 \text { months) }\end{array}$ & 11.8 & 5.12 & 36.2 & 71.3 & 23.5 & 32.8 & 4 & -- & -- & -- & -- \\
\hline $\begin{array}{l}\text { Father } \\
\text { (Post iron therapy at } \\
6 \text { months) }\end{array}$ & 14.2 & 5.02 & 47.1 & 93.6 & 28.6 & 31.2 & 2 & & & & \\
\hline
\end{tabular}


$38 \mathrm{mg} / \mathrm{dl}$, TIBC: $489 \mathrm{mg} / \mathrm{dl}$ and transferrin saturation: $8.7 \%$, thereby explaining the significant anemia.

Molecular diagnosis of the abnormal hemoglobin was confirmed using a method described previously [2]. The characteristic $370 \mathrm{bp}$ fragment (Figure 2) was observed in the agarose gel electrophoresis. Based on the above findings, a diagnosis of coexistent $\mathrm{HbQ}$ India-iron deficiency anemia was made. Following the diagnosis, the patient was placed on iron therapy and she showed improvement as shown in Table 1. At the six-month follow-up, the hematological parameters had returned to normal range. The father, who was initially reluctant to receive iron therapy, was counseled and he eventu-

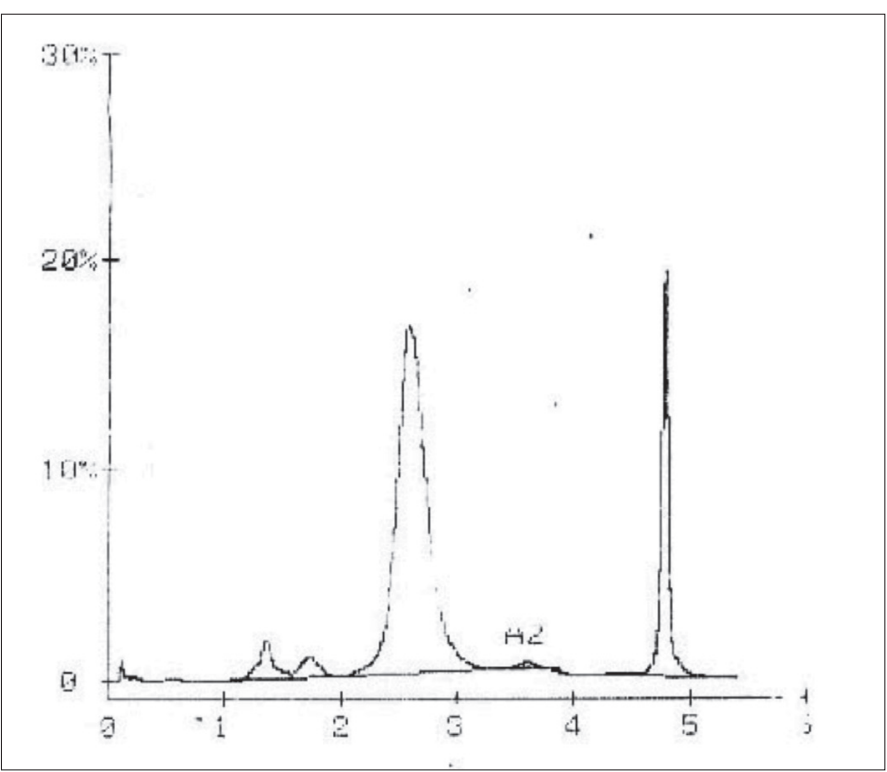

Figure 1. HPLC of the patient showing a peak in the unknown window (4.70-4.90 min)

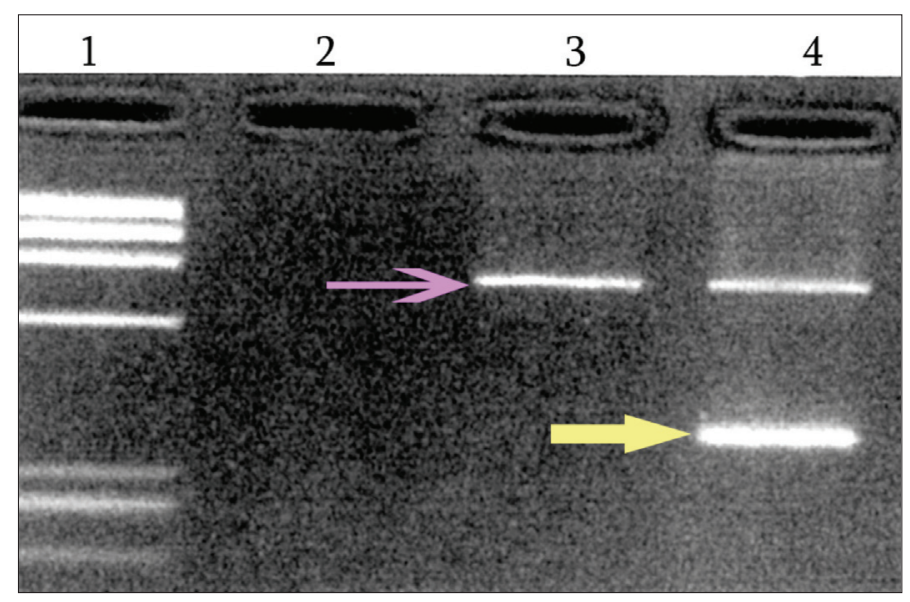

Figure 2. Agarose gel showing the characteristic $370 \mathrm{bp}$ fragment (yellow arrow) in lane 4. Lane 3 - control showing the normal 766 bp fragment (pink arrow), lane 1 - X174 DNA marker fragments and lane 2 - water blank ally agreed. At the six-month follow-up, his hematological parameters had returned to normal range.

Oral informed of consent was ontained from the patient.

\section{Discussion}

$\mathrm{HbQ}$ variants are the alpha globin chain variants due to structural mutations. Three molecular variant types have been documented, namely HbQIndia [1] (alpha 64 Asp to His), HbQ-Thailand (alpha 74 Asp to His) and HbQ-Iran (alpha 75 Asp to His). Normally, HbQ-India is clinically silent. This is because the residue involved, $\alpha 64$ (E 13), is on the surface of the hemoglobin tetramer. However, charge changes at these positions do not affect the properties of the hemoglobin molecule [2].

The majority of the cases reported in the literature are in association with beta- thalassemia [3]. The quantity of the HbQ variant is determined by the ratio of alpha $\mathrm{A}$, alpha $\mathrm{Q}$ and beta $\mathrm{A}$ globin chains. HbQ-India is also known to be affected by the presence of other hemoglobinopathies. Presence of alpha-thalassemia favors the formation of $\mathrm{HbQ}$, whereas beta-thalassemia reduces the formation of HbQ. This has been explained to be due to a post-translational control mechanism [4].

In the present case, the patient and her father improved remarkably on iron therapy. This rules out the possibility of any other associated hemoglobinopathy like alpha-thalassemia.

The definitive method for the identification of HbQ-India is DNA sequencing of the alpha globin and beta globin genes. However, it is an expensive technique and not practical for routine use.

Amplification refractory mutation system (ARMS) polymerase chain reaction (PCR) [2], which is a relatively inexpensive technique, has been adapted to enable the quick identification of HbQ-India.

In conclusion, awareness about HbQ-India is important as it may be confused with $\mathrm{HbS}$ and $\mathrm{HbD}$. HPLC and molecular techniques should be performed in cases with band in the S,D,G region and negative tests for sickling in order to exclude HbQ-India.

\section{Conflict of Interest}

No author of this paper has a conflict of interest, including specific financial interests, relationships, and/or affiliations relevant to the subject matter or materials included in this manuscript. 


\section{References}

1. Sukumaran PK, Merchant SM, Desai MP, Wiltshire BG, Lehmann H. Hemoglobin Q India (alpha 64(E13) aspartic acid to histidine) associated with beta-thalassemia observed in three Sindhi families. J Med Genet 1972;9:436-42.

2. Abraham R, Thomas M, Britt R, Fisher C, Old J. Hb Q-India: an uncommon variant diagnosed in three
Punjabi patients with diabetes is identified by a novel DNA analysis test. J Clin Pathol 2003;56:296-9.

3. Dash S, Huisman TH. Hemoglobin-Q-India (64 (E13) Asp-His) and beta thalassemia: a case report from Punjab (North India). Eur J Haematol 1988;40:281.

4. Qin WB, Baysal E, Wong KF, Molchanova TP, Pobedimskaya DD, Sharma S, Wilson JB, Huisman TH. Quantities of alpha Q chain variants in heterozygotes with and without a concomitant beta-thalassemia trait. Am J Hematol 1994;45:91-3. 